\title{
ISOLASI DAN IDENTIFIKASI BAKTERI PEREDUKSI SULFAT PADA AREA PERTAMBANGAN BATU BARA MUARA ENIM, SUMATERA SELATAN
}

\author{
Muchamad Yusron (much_yusron@yahoo.com) \\ Bibiana W. Lay \\ Anas M. Fauzi \\ Dwi Andreas Santosa \\ Program Studi Pengelolaan Sumberdaya Alam dan Lingkungan, \\ Sekolah Pascasarjana, Institut Pertanian Bogor
}

\begin{abstract}
Sulfate reducing bacteria utilize sulfate as their terminal electron acceptor and reduce it to sulphide. Acid mine drainage, by-products of mining activities, is an acidic sulfate-rich wastewater suitable habitat for sulfate reducing bacteria. Isolation and identification of sulfate reducing bacteria collected from Muara Enim coal mining, South Sumatra was carried out at Laboratory of Environmental Biotechnology, Indonesian Center for Biodiversity and Biotechnology (ICBB), Bogor, and Laboratory of Microbiology, Faculty of Veterinary, Bogor Agricultural University. Postgate B liquid media was used for isolation and purification via serial dilution. Physiological and biochemical characterization was done based on Bergey's Manual of Determinative Bacteriology. Fifteen pure isolates have been isolated with diverse characteristics. Eight isolates can sustain at $\mathrm{pH} 3$, while the rest sustain at $\mathrm{pH} 4$ or above. Sulfate reduction efficiency of each isolates were different, but increased as the $\mathrm{pH}$ increased. The bacteria are classified as Desulfovibrio sp., which is characterized straight rods, motile, non sporeforming and able to grow in simple organic carbon.
\end{abstract}

Keywords : coal mining, identification, isolation, sulfate reducing bacteria

Di alam dikenal beragam bakteri yang memanfaatkan senyawa anorganik sebagai elektron donor atau elektron akseptor dalam aktivitas metabolismenya, salah satunya adalah bakteri pereduksi sulfat. Bakteri pereduksi sulfat memanfaatkan ion sulfur dalam bentuk sulfat $\left(\mathrm{SO}_{4}{ }^{2-}\right)$, tiosulfat $\left(\mathrm{S}_{2} \mathrm{O}_{3}{ }^{2-}\right)$ dan sulfit $\left(\mathrm{SO}_{3}{ }^{2-}\right)$ sebagai akseptor elektron terminal dalam respirasi metabolismenya, yang kemudian direduksi menjadi sulfida. Spesies bakteri pereduksi sulfat yang paling banyak ditemukan adalah dalam sedimen laut karena kandungan sulfat cukup tinggi (Widdel \& Bak, 1992).

Habitat pertumbuhan bakteri pereduksi sulfat cukup luas. Selain di lautan, bakteri ini juga ditemukan di lahan sawah dan perairan darat. Mengingat bakteri ini merupakan bakteri anaerob obligat, bakteri pereduksi sulfat lebih banyak ditemukan pada lingkungan anoksik, terutama di bagian bawah sedimen. Jorgensen (1982) melaporkan bahwa jumlah dan aktivitas bakteri pereduksi sulfat meningkat dengan ketebalan lapisan sedimen. Namun demikian, ada kelompok bakteri pereduksi sulfat yang mampu tumbuh pada kondisi oksik. Hal ini yang menyebabkan ada keragaman bakteri yang tumbuh dalam sedimen. Risatti, Capman, dan Stahl (1994) mengemukakan bahwa kelompok 
Desulfovibrio sp. lebih dominan di bagian atas sedimen, sedangkan Desulfotomaculum sp. banyak ditemukan pada bagian bawah sedimen.

Areal pertambangan merupakan habitat yang cukup sesuai untuk pertumbuhan bakteri pereduksi sulfat. Hal ini dikarenakan aktivitas pertambangan menyebabkan terbentuknya limbah air asam tambang. Air asam tambang merupakan hasil reaksi oksidasi batuan tambang yang kaya akan mineral sulfida. Pirit merupakan mineral sulfida yang banyak dijumpai pada pertambangan batu bara. Batuan sulfida tersebut mengalami oksidasi dengan adanya air dan oksigen, yang dikatalis oleh bakteri pengoksida besi dan sulfur, seperti Thiobacillus ferrooxidans, Leptospirillum ferrooxidans dan Thiobacillus thiooxidans (Schipper, 2004; Cohen, 2005; Johnson \& Hallberg, 2005).

Proses kimia dan biologi dari bahan-bahan mineral sulfida tersebut menghasilkan senyawa sulfat dengan tingkat kemasaman yang tinggi. Pada kondisi demikian hanya mikroorganisme asidofil yang mampu bertahan dan hidup (Ingledew, 1990). Sampai saat ini pengolahan air asam tambang di area pertambangan Muara Enim dilakukan dengan meningkatkan $\mathrm{pH}$ limbah dalam kolam penampungan. Secara alami kolam penampungan limbah tersebut merupakan habitat yang cukup sesuai untuk pertumbuhan bakteri pereduksi sulfat. Keberadaan bakteri pereduksi sulfat akan sangat membantu mengurangi kandungan sulfat pada air asam tambang, sehingga dapat meningkatkan $\mathrm{pH}$ limbah air asam tambang. Bakteri pereduksi sulfat dapat dipergunakan secara bioteknologi untuk mengolah air asam tambang sehingga tidak berbahaya bagi lingkungan.

Penelitian ini dilakukan dengan tujuan untuk mengisolasi dan mengidentifikasi bakteri pereduksi sulfat yang tumbuh di area pertambangan batu bara Muara Enim, Sumatera Selatan.

\section{METODOLOGI}

Sampel lumpur diambil dari lumpur sedimen kolam penampungan air asam tambang pertambangan batu bara PT Bukit Asam, Muara Enim, Sumatera Selatan. Isolasi dan pemurnian bakteri dilaksanakan di Laboratorium Bioteknologi Lingkungan, Indonesian Center for Biodiversity and Biotechnology (ICBB), Bogor, sedangkan identifikasi bakteri dilakukan di Laboratorium Mikrobiologi Fakultas Kedokteran Hewan Institut Pertanian Bogor.

\section{Isolasi}

Bakteri pereduksi sulfat (BPS) diisolasi dari ekosistem air asam di kolam penampungan air asam tambang industri batu bara PT Bukit Asam, Sumatera Selatan. Sampel tanah diambil dari sedimen (bagian bawah) kolam, sesuai dengan metode pengambilan sampel mikrobiologi tanah. Sampel diambil sebanyak 100-200 g tanah, dimasukkan ke dalam tabung berwarna gelap, dan dikemas dalam kondisi anaerob.

Isolasi BPS mengikuti metode Atlas (1993) dengan komposisi media cair Postgate B yang disederhanakan. Komposisi untuk satu liter media cair terdiri atas natrium laktat $(8 \mathrm{~mL})$, magnesium sulfat $(1,0 \mathrm{~g})$, ammonium klorida $(0,5 \mathrm{~g})$, kalium dihidrogen fosfat $(1,0 \mathrm{~g})$, besi fosfat $(0,1 \mathrm{~g})$ dan asam askorbat $(0,5 \mathrm{~g})$, glukosa $(0,1 \mathrm{~g})$, kalsium klorida $(0,1 \mathrm{~g})$, natrium sulfat $(0,5 \mathrm{~g})$, dan ekstrak khamir $(0,1 \mathrm{~g})$. Pengaturan $\mathrm{pH} 4$ dilakukan dengan penambahan asam sulfat sebelum disterilisasi.

Suspensi sampel dibuat dengan cara dimasukkan $1 \mathrm{~g}$ sampel tanah ke dalam tabung reaksi dan ditambahkan larutan garam fisiologis $(0,85 \%)$ steril hingga $10 \mathrm{~mL}$, kemudian dihomogenisasi dengan vorteks. Suspensi sampel tersebut dipipet $1 \mathrm{~mL}$ dan dimasukkan ke dalam tabung reaksi dan ditambahkan larutan garam fisiologis hingga $10 \mathrm{~mL}$, lalu dihomogenisasi. Selanjutnya dilakukan 
pengenceran hingga $10^{3}$, dan diambil $1 \mathrm{~mL}$ dimasukkan ke dalam tabung reaksi yang berisi $1 / 3$ media yang telah disterilkan, kemudian ditambahkan media steril secara perlahan-lahan sampai penuh dan ditutup rapat. Media tersebut kemudian diinkubasi pada suhu $35^{\circ} \mathrm{C}$.

Tumbuhnya BPS ditandai dengan berubahnya media menjadi berwarna hitam (dengan terbentuknya sulfida) yang menunjukkan aktivitas BPS. Pengamatan dilakukan saat perubahan warna hingga seluruh media berwarna hitam. Isolat yang tumbuh diberi skor tingkat kepekatan warna hitamnya.

\section{Pemurnian}

Pemurnian isolat dilakukan dengan metode pengenceran (Stanier, Adelberg, \& Ingraham, 1982). Isolat yang diperoleh dikocok dengan baik hingga terbentuk suspensi. Tingkat pengenceran sepuluh kali dilakukan dengan memindahkan secara aseptik $1 \mathrm{~mL}$ suspensi mikrob ke dalam tabung yang berisi $9 \mathrm{~mL}$ larutan fisiologi 0,85\% lalu dihomogenisasi. Suspensi tersebut diencerkan lebih lanjut dengan cara yang sama hingga pada tingkat pengenceran $10^{12}$. Suspensi dipindahkan secara aseptik sebanyak $1 \mathrm{~mL}$ ke dalam tabung ulir yang telah berisi media cair steril 1/3 bagian, lalu media ditambahkan secara perlahan-lahan hingga penuh dan ditutup rapat dan diinkubasi pada suhu $35{ }^{\circ} \mathrm{C}$. Pengamatan dilakukan terhadap waktu pertumbuhan biakan mulai dari munculnya warna hitam hingga seluruh tabung menghitam. Isolat yang tumbuh pada tingkat pengenceran terakhir diindikasikan sebagai biakan dengan satu jenis sel BPS.

\section{Seleksi}

Seleksi dilakukan dengan pembiakan isolat murni dalam media cair dengan variasi $\mathrm{pH}$ dari 7 , $6,5,4$, dan 3 . Sebanyak $1 \mathrm{~mL}$ suspensi mikrob dipindahkan secara aseptik ke dalam tabung ulir yang telah berisi $1 / 3$ bagian media cair ( $\mathrm{pH} 6)$, kemudian ditambahkan media perlahan-lahan hingga penuh dan diinkubasi pada suhu $35^{\circ} \mathrm{C}$. Perlakuan yang sama dilakukan terhadap semua isolat yang akan dikarakterisasi dengan variasi $\mathrm{pH}$. Pada hari ke 21 dilakukan pengukuran sisa sulfat dan $\mathrm{pH}$ larutan. Isolat yang dipilih adalah yang mampu tumbuh pada $\mathrm{pH}$ rendah dengan kemampuan mereduksi sulfat dan meningkatkan $\mathrm{pH}$ media yang tinggi.

\section{Identifikasi}

Identifikasi dilakukan hanya pada isolat yang dianggap unggul. Identifikasi dilakukan dengan media padat maupun media cair. Untuk penentuan tipe morfologi, pewarnaan Gram dan pewarnaan spora isolat diambil dari biakan media padat. Masing-masing isolat ditumbuhkan pada media selektif dengan komposisi hara yang sama dengan media cair. Sebanyak $1 \mathrm{~mL}$ suspensi mikrob dipindahkan secara aseptik dengan mikropipet ke dalam cawan petri yang telah berisi media padat steril. Suspensi mikrob disebar secara merata di permukaan media, kemudian dimasukkan ke dalam tabung anaerob yang dilengkapi dengan gaspak dan indikator. Biakan diinkubasi pada suhu $35{ }^{\circ} \mathrm{C}$ selama lebih dari 7 hari.

Setiap koloni yang tumbuh dipindahkan secara aseptik ke dalam agar miring dan diinkubasi secara anaerob. Koloni yang tumbuh dibiakkan lagi ke dalam media cair dengan cara yang sama. Isolat tersebut diidentifikasi lebih lanjut dengan uji fisiologis dan biokimia. Karakterisasi fisiologis dan 
biokimia dilakukan dengan berpedoman pada Bergey's Manual of Determinative Bacteriology (Holt Holt, Krieg, Sneath, Staley, \& Williams, 1994).

\section{HASIL DAN PEMBAHASAN}

\section{Isolasi Bakteri Pereduksi Sulfat}

Hasil isolasi bakteri pereduksi sulfat dari lumpur di kolam penampungan limbah air asam tambang di area pertambangan PT. Bukit Asam Muara Enim memperlihatkan bahwa bakteri pereduksi sulfat ditemukan di semua kolam penampungan. Kondisi kolam penampungan yang banyak mengandung sulfat dan $\mathrm{pH}$ rendah merupakan habitat yang sesuai untuk pertumbuhan bakteri pereduksi sulfat. Namun demikian kelompok bakteri tersebut mempunyai karakteristik yang berbeda, dilihat dari waktu tumbuh dan kemampuan mereduksi sulfat. Beberapa kelompok bakteri mampu tumbuh cepat, yakni antara 6-8 hari setelah inkubasi, namun demikian ditemukan pula kelompok bakteri yang membutuhkan waktu 21 hari untuk tumbuh.

Kemampuan kelompok bakteri untuk mereduksi sulfat juga berbeda. Kemampuan mereduksi sulfat diindasikan dengan tingkat kepekatan larutan dan warna hitam pada tabung reaksi. Sesuai dengan reaksi reduksi sulfat, $\mathrm{SO}_{4}{ }^{2-}$ direduksi oleh bakteri pereduksi sulfat menjadi $\mathrm{S}^{2-}$, dan bereaksi dengan ion logam membentuk logam sulfida yang berwarna hitam dan tidak larut. Oleh karena itu, makin banyak logam sulfida yang terbentuk, larutan dalam tabung akan semakin pekat (Gambar 1). Keragaman karakteristik kelompok bakteri pereduksi sulfat tersebut disebabkan perbedaan ekosistem tempat tumbuhnya, seperti $\mathrm{pH}$, konsentrasi sulfat dan ketebalan lumpur dalam kolam. Hasil pengukuran pH dan kandungan sulfat di beberapa titik pengamatan memperlihatkan adanya perbedaan tersebut (Tabel 1). Nilai pH bervariasi antara 2,92 - 4,05, sedang kandungan $\mathrm{SO}_{4}{ }^{2-}$ berkisar antara $800-1150 \mathrm{mg} / \mathrm{L}$. Perbedaan kondisi ekosistem mikro kolam penampungan limbah menyebabkan perbedaan isolat bakteri yang tumbuh dan beradaptasi pada kondisi ekosistem tersebut.

Keragaman karakteristik bakteri pereduksi sulfat sangat dipengaruhi oleh kondisi lingkungan, kemasaman lingkungan, kedalaman sedimen, ketersediaan energi dari bahan organik, dan kandungan sulfat. Hal ini sejalan dengan hasil penelitian lain yang mengemukakan bahwa faktor lingkungan mempengaruhi keragaman jenis dan karakteristik bakteri pereduksi sulfat antara lain kemasaman lingkungan (Bractova, Groudev, \& Georgiev, 2002), kedalaman sedimen (Hoehler, Alperin, Albert, \& Martens, 2001; Jorgensen, 1982), ketersediaan energi dari bahan organik (Hoehler et al., 2001; Liamleam \& Annachhtre, 2007), dan kandungan sulfat (Icgen \& Harrison, 2006). Icgen dan Harrison (2006) melaporkan bahwa kandungan sulfat menentukan kelompok bakteri pereduksi sulfat yang dominan tumbuh pada suatu ekosistem. 


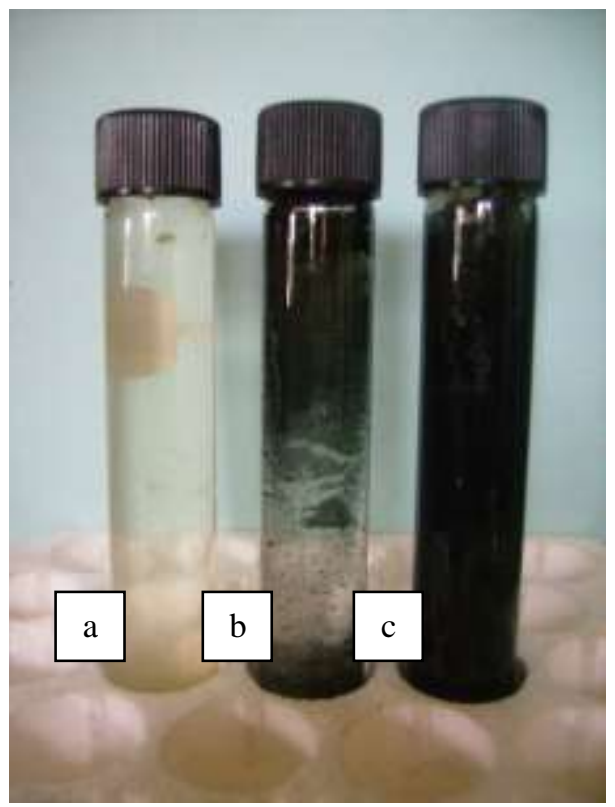

Gambar 1. Indikasi terjadinya reduksi sulfat oleh bakteri pereduksi sulfat hasil isolasi di kolam penampungan limbah air asam tambang di Muara Enim, Sumatera Selatan : (a) kontrol, (b) hitam tipis hampir merata dan (c) hitam pekat merata

Perbedaan karakteristik bakteri pereduksi sulfat mungkin juga disebabkan oleh perbedaan kedalaman contoh yang diambil. Contoh lumpur diambil pada kedalaman antara $50 \mathrm{~cm}$ sampai 150 $\mathrm{cm}$. Perbedaan kedalaman lumpur tersebut akan mempengaruhi jumlah oksigen yang terlarut, sehingga mempengaruhi jenis dan aktivitas bakteri yang tumbuh. Beberapa kelompok bakteri pereduksi sulfat mampu tumbuh pada kondisi oksik, sedangkan kelompok bakteri lain membutuhkan kondisi yang betul-betul anoksik. Pertumbuhan bakteri pereduksi sulfat yang anaerob obligat terganggu dengan adanya oksigen terlarut. Risatti et al. (1994) mengemukakan bahwa kelompok Desulfovibrio lebih dominan di bagian atas dari sedimen. Sedangkan Jorgensen (1982) melaporkan bahwa jumlah dan aktivitas bakteri pereduksi sulfat meningkat dengan ketebalan lapisan sedimen.

Tabel 1. Nilai pH Kandungan $\mathrm{SO}_{4}{ }^{2-}$ Contoh Air Asam Tambang di Muara Enim, Sumatera Selatan

\begin{tabular}{lcrcc}
\hline \multicolumn{1}{c}{ Kode Contoh } & \multicolumn{2}{c}{ Posisi } & pH & SO $_{4^{2}}{ }^{-}(\mathbf{m g} / \mathbf{L})$ \\
\hline PIT G & $0342,112 \mathrm{~S}$ & $10346,409 \mathrm{E}$ & 2,92 & 1050 \\
ALP & $0343,441 \mathrm{~S}$ & $10347,190 \mathrm{E}$ & 2,95 & 925 \\
KPL & $0341,418 \mathrm{~S}$ & $10345,779 \mathrm{E}$ & 2,92 & 1150 \\
TOWER & $0341,981 \mathrm{~S}$ & $10347,757 \mathrm{E}$ & 3,41 & 980 \\
KTU & $0342,889 \mathrm{~S}$ & $10347,324 \mathrm{E}$ & 3,48 & 875 \\
TUPAK & $0341,754 \mathrm{~S}$ & $10347,283 \mathrm{E}$ & 3,24 & 825 \\
LINTANG & $0341,421 \mathrm{~S}$ & $10345,990 \mathrm{E}$ & 3,56 & 850 \\
KANDIS & $0343,939 \mathrm{~S}$ & $10347,391 \mathrm{E}$ & 3,97 & 840 \\
KPL MERE & $0342,770 \mathrm{~S}$ & $10347,658 \mathrm{E}$ & 4,05 & 800 \\
LIMAU TEMBE & $0341,292 \mathrm{~S}$ & $10347,810 \mathrm{E}$ & 3,75 & 905 \\
\hline
\end{tabular}




\section{Pemurnian Bakteri Pereduksi Sulfat}

Dari 26 kelompok bakteri yang telah diiolasi, diperoleh 15 isolat murni bakteri pereduksi sulfat. Isolat murni ini merupakan bakteri yang mampu tumbuh pada salah satu tabung pada tingkat pengenceran terakhir. Hasil ini memperlihatkan bahwa tidak semua bakteri pereduksi sulfat mampu tumbuh pada kondisi spesifik. Dari hasil permurnian ini terlihat bahwa isolat yang tidak dapat dimurnikan adalah kelompok bakteri yang mempunyai kemampuan mereduksi sulfat rendah.

\section{Karakteristik Isolat Murni Bakteri Pereduksi Sulfat}

Beberapa karakteristik isolat bakteri pereduksi sulfat yang telah dimurnikan disajikan pada Tabel 2. Karakteristik isolat murni beragam dalam beradaptasi dengan lingkungan sekitarnya dan kemampuan mereduksi sulfat. Hasil pengujian pada media dengan konsentrasi sulfat sebesar $500 \mathrm{mg} / \mathrm{L}$, dari 15 isolat murni, hanya 8 isolat yang mampu tumbuh pada pH 3. Tujuh isolat murni lainnya hanya mampu tumbuh pada $\mathrm{pH}$ di atas 4 . Kemampuan bakteri pereduksi sulfat beradaptasi dengan kondisi masam berkaitan dengan karakteristik sel bakteri.

Tabel 2.Kemampuan Reduksi Sulfat Isolat BPS pada Konsentrasi Sulfat 500 mg/L dan pH Awal 3, 4 dan 6

\begin{tabular}{|c|c|c|c|c|c|c|c|c|c|}
\hline \multirow[b]{2}{*}{ Isolat } & \multicolumn{3}{|c|}{ pH 6} & \multicolumn{3}{|c|}{ pH 4} & \multicolumn{3}{|c|}{ pH 3} \\
\hline & $\mathrm{pH}$ & $\begin{array}{l}\mathrm{SO}_{4}{ }^{2-} \\
\text { (mg/L) }\end{array}$ & $\begin{array}{c}\% \\
\text { Reduksi }\end{array}$ & $\mathrm{pH}$ & $\begin{array}{l}\mathrm{SO}_{4}{ }^{2-} \\
(\mathrm{mg} / \mathrm{L})\end{array}$ & $\begin{array}{c}\% \\
\text { Reduksi }\end{array}$ & $\mathrm{pH}$ & $\begin{array}{l}\mathrm{SO}_{4}{ }^{2-} \\
(\mathrm{mg} / \mathrm{L})\end{array}$ & $\begin{array}{c}\% \\
\text { Reduksi }\end{array}$ \\
\hline ICBB 8818 & 8,32 & 41,06 & 91,79 & 7,65 & 68,54 & 86,29 & 6,74 & 78,58 & 84,28 \\
\hline ICBB 8815 & 8,15 & 43,25 & 91,35 & 7,60 & 69,44 & 86,11 & 6,57 & 80,24 & 83,95 \\
\hline ICBB 8816 & 7,91 & 44,89 & 91,02 & 7,22 & 70,12 & 85,98 & 6,68 & 84,64 & 83,07 \\
\hline ICBB 8813 & 7,90 & 45,32 & 90,94 & 7,10 & 70,24 & 85,95 & 6,59 & 106,08 & 78,78 \\
\hline ICBB 8819 & 7,80 & 45,06 & 90,99 & 7,40 & 90,64 & 81,87 & 6,40 & 106,82 & 78,64 \\
\hline ICBB 8825 & 7,75 & 57,80 & 88,44 & 7,10 & 89,50 & 82,10 & 6,59 & 115,26 & 76,95 \\
\hline ICBB 8817 & 7,70 & 62,40 & 87,52 & 7,00 & 112,58 & 77,48 & 6,40 & 142,67 & 71,47 \\
\hline ICBB 8811 & 7,70 & 60,58 & 87,88 & 7,00 & 92,58 & 81,48 & $\mathrm{tt}$ & - & - \\
\hline ICBB 8814 & 7,60 & 90,26 & 81,95 & 7,0 & 120,25 & 75,95 & 6,00 & 140,28 & 71,94 \\
\hline ICBB 8812 & 7,60 & 78,29 & 84,34 & 7,00 & 108,11 & 78,38 & $\mathrm{tt}$ & - & - \\
\hline ICBB 8823 & 7,50 & 95,25 & 80,95 & 7,05 & 115,28 & 76,94 & $\mathrm{tt}$ & - & - \\
\hline ICBB 8824 & 7,30 & 100,85 & 79,83 & 7,00 & 125,58 & 74,88 & $\mathrm{tt}$ & - & - \\
\hline ICBB 8822 & 7,20 & 113,25 & 77,35 & 6,90 & 133,12 & 73,38 & $\mathrm{tt}$ & - & - \\
\hline ICBB 8821 & 7,20 & 120,21 & 75,96 & 6,90 & 140,25 & 71,95 & $\mathrm{tt}$ & - & - \\
\hline ICBB 8820 & 7,20 & 126,25 & 74,75 & 7,00 & 136,15 & 72,77 & $\mathrm{tt}$ & - & - \\
\hline
\end{tabular}

Keterangan $: \mathrm{tt}=$ tidak tumbuh 
Kemampuan isolat bakteri pereduksi sulfat juga beragam, namun efisiensi reduksi sulfat semua isolat meningkat dengan peningkatkan nilai pH. Pada $\mathrm{pH} 6$ efisiensi reduksi sulfat berkisar antara $74,75 \%$ sampai $91,79 \%$. Kemampuan terendah diperoleh isolat ICBB 8820 , sedangkan isolat ICBB 8818 mempunyai kemampuan mereduksi sulfat paling tinggi, yakni sebesar 91,79\%. Penurunan $\mathrm{pH}$ menurunkan kemampuan bakteri mereduksi sulfat. Pada $\mathrm{pH} 6$, isolat ICBB 8820 mampu mereduksi sebesar $74,75 \%$, berkurang menjadi $72,77 \%$ pada $\mathrm{pH} 4$, dan tidak mampu tumbuh pada pH 3. Sedangkan kemampuan reduksi isolat ICBB 8818 mencapai 91,79\% pada pH 6, tetapi hanya sebesar $84,28 \%$ pada $\mathrm{pH} 3$. Pada $\mathrm{pH} 3$ total sulfat yang tereduksi oleh 8 isolat yang mampu tumbuh berkisar antara $71,47 \%$ sampai $84,28 \%$.

\section{Identifikasi Bakteri Pereduksi Sulfat}

Karakteristik 8 isolat unggul bakteri pereduksi sulfat disajikan pada Tabel 3. Identifikasi ini dilakukan berdasarkan Bergey's Manual of Determinative Bacteriology, yang didasarkan pada beberapa karakteristik antara lain pewarnaan Gram, bentuk sel, bentuk koloni, warna koloni, motilitas, kondisi lingkungan tumbuh, pembentukan spora dan sumber karbon.

Berdasarkan Bergey's Manual of Determinative Bacteriology, hasil identifikasi 8 isolat unggul, diperoleh bahwa semua isolat tersebut termasuk dalam kelompok Desulfovibrio sp. Desulfovibrio sp. adalah bakteri pereduksi sulfat dengan karakteristik antara lain bersifat mesofilik, gram negatif, batang, tidak membentuk spora dan hanya menunjukkan pertumbuhan pada kondisi anaerob. Bakteri ini tergolong bakteri yang mengoksidasi karbon organik secara tidak sempurna. Desulfovibrio sp. terutama memanfaatkan laktat sebagai sumber karbon, dan mengoksidasinya menjadi asetat. Rzeczycka dan Blaszczyk (2005) dan Cord-Ruwisch, Ollivier, dan Garcia, (1986) melaporkan bahwa Desulfovibrio tumbuh lebih baik dengan laktat sebagai sumber karbon. Namun demikian kelompok bakteri ini juga dapat memanfaatkan sumber karbon lain, seperti malat, pyruvat, propionat, butyrat, dalam mereduksi sulfat (Postagate \& Campbell, 1966). Desulfovibrio sp. memanfaatkan sumber karbon antara lain laktat, dan mengoksidasinya menjadi asetat.

Desulfovibrio sp. merupakan kelompok bakteri pereduksi sulfat yang paling banyak ditemui di alam, dan paling banyak ditemui pada sedimen lingkungan air tawar (Holmer \& Storkholm, 2001). Hasil isolasi dan pemurnian bakteri pereduksi sulfat yang tumbuh di lingkungan pertambangan batu bara menunjukkan bahwa Desulfovibrio sp. merupakan bakteri pereduksi sulfat yang paling dominan. Hal ini sesuai dengan hasil temuan Icgen dan Harrison (2006), dimana Desulfovibrio sp. ditemui lebih dominan pada ekosistem dengan kandungan sulfat yang tinggi dibandingkan dengan kelompok bakteri pereduksi sulfat lainnya.

Desulfovibrio sp. merupakan bakteri pereduksi sulfat yang mampu hidup pada kondisi yang sedikit oksik. Karakteristik ini berkaitan dengan kemampuan bakteri menghasilkan enzim yang mampu melindungi sel dari stres oksigen. Berkaitan dengan kemampuan Desulfovibrio sp. hidup dalam kondisi sedikit oksik, Fournier et al., (2003) mengemukakan bahwa dalam sel Desulfovibrio sp. terdapat enzim superoxide reductase (Sor) yang berperan dalam mereduksi oksigen. Oleh karena itu kelompok bakteri ini sering ditemukan di bagian atas sedimen (Risatti et al., 1994). Walaupun demikian Desulfovibrio sp. tetap membutuhkan kondisi anaerob untuk dapat mempertahankan perkembangan selnya. Bakteri ini hanya mampu tumbuh dengan baik pada kondisi oksik selama tidak lebih dari 24 jam, setelah itu pertumbuhannya akan turun drastis (Cypionka, Widdel, \& Pfenning, 1985). 
Tabel 3. Karakteristik Delapan Isolat Unggul Bakteri Pereduksi Sulfat

\begin{tabular}{|c|c|c|c|c|c|c|c|c|}
\hline \multirow{2}{*}{ Karakteristik } & \multicolumn{8}{|c|}{ Isolat } \\
\hline & ICBB 8813 & ICBB 8814 & ICBB 8815 & ICBB 8816 & ICBB 8817 & ICBB 8818 & ICBB 8819 & ICBB 8825 \\
\hline $\begin{array}{l}\text { Pewarnaan } \\
\text { Gram }\end{array}$ & Negatif & Negatif & Negatif & Negartif & Negatif & Negatif & Negatif & Negatif \\
\hline Bentuk Sel & Batang & Batang & Batang & Batang & Batang & Batang & Batang & Batang \\
\hline Bentuk Koloni & $\begin{array}{l}\text { Bulat tak } \\
\text { beraturan }\end{array}$ & $\begin{array}{l}\text { Bulat tak } \\
\text { beraturan }\end{array}$ & $\begin{array}{l}\text { Bulat tak } \\
\text { beraturan }\end{array}$ & $\begin{array}{l}\text { Bulat tak } \\
\text { beraturan }\end{array}$ & $\begin{array}{l}\text { Bulat tak } \\
\text { beraturan }\end{array}$ & $\begin{array}{l}\text { Bulat tak } \\
\text { beraturan }\end{array}$ & $\begin{array}{l}\text { Bulat tak } \\
\text { beraturan }\end{array}$ & $\begin{array}{l}\text { Bulat tak } \\
\text { beraturan }\end{array}$ \\
\hline Warna Koloni & Putih - krem & Putih - krem & Putih - krem & Putih - krem & Putih - krem & Putih - krem & Putih - krem & Putih - krem \\
\hline \multicolumn{9}{|l|}{ Ukuran Sel } \\
\hline Panjang $(\mu \mathrm{m})$ & $1,12-1,75$ & $1,05-2,12$ & $1,09-2,22$ & $1,07-1,86$ & $1,02-1,92$ & $1,07-1,72$ & $1,08-1,96$ & $1,01-2,02$ \\
\hline Lebar ( $\mu \mathrm{m})$ & $0,70-1,03$ & $0,68-1,06$ & $0,69-1,01$ & $0,68-1,00$ & $0,75-1,00$ & $0,71-1,05$ & $0,65-1,01$ & $0,68-1,09$ \\
\hline Motilitas & + & + & + & + & + & + & + & + \\
\hline Anaerob & + & + & + & + & + & + & + & + \\
\hline Endospora & - & - & - & - & - & - & - & - \\
\hline Sumber karbon & Laktat & Laktat & Laktat & Laktat & Laktat & Laktat & Laktat & Laktat \\
\hline $\begin{array}{l}\text { Suhu } \\
\text { pertumbuhan }{ }^{\circ} \mathrm{C}\end{array}$ & $25-40$ & $25-40$ & $25-40$ & $25-40$ & $25-40$ & $25-40$ & $25-40$ & $25-40$ \\
\hline Penghasil sulfida & + & + & + & + & + & + & + & + \\
\hline Species & $\begin{array}{c}\text { Desulfovibrio } \\
\text { sp. }\end{array}$ & $\begin{array}{c}\text { Desulfovibrio } \\
\text { sp. }\end{array}$ & $\begin{array}{c}\text { Desulfovibrio } \\
\text { sp. }\end{array}$ & $\begin{array}{c}\text { Desulfovibrio } \\
\text { sp. }\end{array}$ & $\begin{array}{c}\text { Desulfovibrio } \\
\text { sp. }\end{array}$ & $\begin{array}{c}\text { Desulfovibrio } \\
\text { sp. }\end{array}$ & $\begin{array}{c}\text { Desulfovibrio } \\
\text { sp. }\end{array}$ & $\begin{array}{c}\text { Desulfovibrio } \\
\text { sp. }\end{array}$ \\
\hline
\end{tabular}




\section{KESIMPULAN}

Berdasarkan penelitian yang dilakukan, dapat disimpulkan sebagai berikut.

1. Lima belas isolat murni bakteri pereduksi sulfat berhasil diisolasi dari area pertambangan batu bara Muara Enim, Sumatera Selatan.

2. Karakteristik masing-masing isolat berbeda. Delapan isolat mampu tumbuh pada pH 3, tujuh isolat lainnya hanya mampu tumbuh pada $\mathrm{pH}$ di atas 4 . Kemampuan isolat bakteri pereduksi sulfat juga beragam, namun efisiensi reduksi sulfat semua isolat meningkat dengan peningkatkan nilai $\mathrm{pH}$.

3. Hasil identifikasi 8 isolat unggul, diperoleh bahwa semua isolat tersebut termasuk dalam kelompok Desulfovibrio sp., bakteri yang berbentuk batang, motil, tidak membentuk spora dan menggunakan laktat sebagai sumber organik.

\section{REFERENSI}

Atlas, R.M. (1993). Hand book of microbiological media. Boca Raton, Florida: CRC Press Inc. Bractova, S., Groudev, S., \& Georgiev, P. (2002). The effect of some essential environmental factors on microbial dissimilatory sulphate reduction. Annual of the University of Mining and Geology St Ivan Ritski, Vol 44-45, Part II, Mining and Mineral Processing. pp. 123-127.

Cohen, R.R.H. (2005). Use microbes for cost reduction of metal removal from metals and mining industry waste streams. Journal of Cleaner Production, 5, 1-2.

Cord-Ruwisch, R., Ollivier, B., \& Garcia, J.L. (1986). Fructose degradation by Desulfovibrio sp. In pure culture and in coculture with Methanospirillum hungatei. Current Microbiology, 13, 285289.

Cypionka, H., Widdel, F., \& Pfenning, N. (1985). Survival of sulfate-reducing bacteria after oxygen stress, and growth in sulfate-free oxygen sulfide gradients. FEMS Microbiology and Ecology, $31,39-45$.

Fournier, M., Zhang, Y., Wildschut, J.D., Dolla, A., Voordouw, J.K., \& Schriemer, D.C. (2003). Function of oxygen resistance proteins in the anaerobic sulfate-reducing bacterium Desulfovibrio vulgaris Hildenborough. Journal of Bacteriology, 185 (1), 71-79.

Hoehler, T.M., Alperin, M.J. , Albert, D.B., \& Martens, C.S. (2001). Apparent minimum free energy requirements for methanogenic archaea and sulfate-reducing bacteria in an anoxic marine sediment. FEMS Microbiology and Ecology, 38, 33-41.

Holmer, M., \& Storkholm, P. (2001). Sulphate reduction and sulphur cycling in lake sediments: A review. Freshwater Biology, 46, 431-451

Holt, J.G., Krieg, N.R., Sneath, P.H.A., Staley, J.T., \& Williams, S.T. (1994). Bergey's manual of determinative bacteriology. Baltimore, USA: Williams and Wilkins.

Icgen, B., \& Harrison, S. (2006). Identification of population dynamics in sulfate-reducing consortia on exposure to sulfate. Research on Microbiology, 157, 922-927.

Ingledew, W.J. (1990). Acidophiles (Chapter 2). C. Edwards (Ed). Microbiology of extreme environments. Open University Press, Milton Keynes. 33-54.

Johnson, D.B., \& Halberg, K.B. (2005). Acid mine drainage remediation options: A review. Science of the Total Environment, 338, 3-14.

Jorgensen, B.B. (1982). Mineralization of organic matter in sea bed: The role of sulphate reduction. Nature, 296, 643-645. 
Liamleam, W., \& Annachhatre, A.P. (2007). Electron donors for biological sulfate reduction. Biotechnoloy Advance, $25,452-463$.

Postgate J.R., \& Campbell, L.L. (1966). Classification of desulfovibrio species, the nonsporulating sulfate-reducing bacteria. Bactiorology Review, 30(4), 732-738.

Risatti, J.B., Capman, W.C., \& Stahl, D.A. (1994). Community structure of a microbial mat: The phylogenetic dimension. Proceeding of National Academy Science. USA, 10173-10177.

Rzeczycka, M. \& Blaszczyk, B. (2005). Growth and activity of sulphate-reducing bacteria in media containing phosphogypsum and different source of carbon. Polish Journal of Environemntal Studies, 14 (6), 891-895.

Stanier, R.Y., Adelberg, E.A., \& Ingraham, J. (1982). The Microbial World. New Jersey: Practice Hall Inc. Englewood Cliffs.

Schipper, A. (2004). Biogeochemistry of metal sulfide oxidation in mining environments, sediment and soils. In Amend, J.P., Edwards, K.J. \& Lyons, T.W. (Eds). Sulfur BiogeochemistryPast and Present. Geological Soc. of America. Special Paper, 379, 49-62.

Widdel, F., \& Bak, F. (1992). Gram-negative mesophilic sulfate-reducing bacteria. In Balows A. et al. (Eds). The Prokaryotes. ( $\left.2^{\text {nd }} \mathrm{ed}\right)$. A Handbook on the Biology of Bacteria: Ecophysiology, Isolation, Identification, Application. New York : Springer-Verlag. 